\title{
American-Style Capitalism and Income Disparity: The Challenge of Social Anarchy
}

Vernon M. Briggs, Jr.

With the end of the Cold War on Christmas Day 1991, the word "capitalism" seems also to have disappeared from public discussions. In its place, there is much talk about "the market" as an impersonal object and praise for its alleged merits as a guide to economic decision making. But there is surprisingly little attention paid to the actual state of capitalism itself-especially as it is evolving in the United States in the late 1990s. Yet it is capitalism as an economic system that defines "the market," and it is the policies and institutions of capitalist countries that actually shape market outcomes. Thus, it is of consequence to ponder how this process is working. For just as its chief intellectual rival-communism-collapsed from within because centralized socialism could not keep pace with capitalist economies that were consistently revolutionizing the frontiers of knowledge, supporters of capitalism also must watch for signs of its own undermining.

With regard to its outward manifestations, the American variant of capitalism seems healthy and vibrant. The contemporary economic indicators are essentially positive: unemployment is falling; inflation is low and essentially stable; profits are generally high; industrial production is close to capacity; future expectations by both consumers and producers are optimistic; and the stock market averages are at or close to record levels. But, on the other hand, the social indicators that describe the quality of contemporary life are almost universally morbid and depressing. Divorce rates are staggering; the use of illicit drugs is widespread; bankruptcies are increasing; illegal immigration is massive; teen-age pregnancies are at epidemic levels; homelessness is spreading; less than half the voting age population actually votes in national elections; membership in trade unions has fallen to the same low levels that

The author is Professor of Labor Economics, Comell University. This paper was presented at the annual meeting of the Association for Evolutionary Economics, Chicago, Illinois, January 3-5, 1998. 
last existed in the depths of the depression in the early 1930s; the percentage of children living in poverty, the incidence of violent crimes, the magnitude of adult illiteracy, and the number of persons reported to be AIDS-HIV infected are all the highest in the industrial world; and more than a million persons are in jails and prisons (more than half of whom are blacks) with more than twice that number either on parole or on bail. Moreover, stories of the prevalence of violent urban "street gangs," oppressive manufacturing "sweatshops," and armed militias in rural areas are commonplace on evening news shows. So if the economic indicators are so good, why are the social indicators so bad?

Ironically, a plea for a critical assessment of the state of capitalism in the United States was made in 1997 by one of the foremost beneficiaries of this free market era-the billionaire financier George Soros. Writing in Atlantic Monthly, he bluntly stated: "Although I have made a fortune in the financial markets, I now fear that the untrammeled intensification of laissez-faire capitalism and the spread of market values into all areas of life is endangering our open and democratic society. The main enemy . . . is no longer the communist but the capitalist threat" [Soros 1997, 45]. Soros sees what many economic conservatives in academia, business, the media, and government refuse to recognize: namely, that "too much competition and too little cooperation can cause intolerable inequities and instability" [Soros 1997, 47].

By far the most significant of the emerging outcome "inequities" in the United States pertains to the widening economic disparity among the population. In early 1997, U.S. Secretary of Labor Robert Reich summed up the situation as follows: "Over 15 years ago, inequality of income, wealth, and opportunity began to widen and the gap today is wider than at any time in living memory" [Reich 1997, E-13]. Because the United States has always been among the extreme examples of consumer-driven capitalism, it is questionable-given this disparity among its population-how long it can maintain social order when increasing numbers of persons are left out of the banquet while a few are allowed to gorge.

\section{The Consumer Economy}

Factually, consumption in the United States totaled more than $\$ 5.1$ trillion in 1996, and that sum represented more than 67 percent of the nation's gross domestic product [Economic Report 1997, 300]. Yet, no one really needs to be told the economic statistics to know that American-style capitalism is consumer-driven [Sagoff 1997]. Anyone who has ever visited a major shopping mall or who has ever watched television advertising broadcast directly into the living rooms and bedrooms of virtually every household knows intuitively that consumption is the imperative of our economy. The "lifestyles of the rich and famous" are on daily display for all to see-and to covet. 
American-style capitalism seeks to make the citizenry want what it has to offer: material well-being. Engineering power-called technology-seems to be capable of continually increasing productivity if the consumer demand is forthcoming. Producers who produce what consumers want have the possibility to reap huge profits. But in this age of mega-enterprises, few producers are content to let the foibles of consumers determine their fate. Hence, producers seek to influence consumers about what they want [Galbraith 1967, 204-207, 273]. Thus, through massive and pervasive advertising, the system seeks to create wants and anxieties that can only be satisfied by more and more goods. It offers the lure of material satisfaction in one's lifetime. No longer does one have to wait for the afterlife to enjoy the good things. If one has the income, one can consume and enjoy in the "here and now." Advertising is designed to urge and to convince people to buy on impulse; to satisfy immediate wants; to seek immediate gratification; to avoid savings; to stay young; to have fun; and to accept no limits on freedom. American-style capitalism and societal permissiveness go hand-in-hand. Consumption is the fire that fuels the American economy. For this reason, American capitalism has had deep and fundamental support-both economically and ideologically-from most of its citizens and its workers.

American-style capitalism, with its emphasis on consumerism, has offered the prospect that it can defy the Marxian time bomb that competitive capitalism would spawn class divisions and class hatreds between the "haves" and the "have nots." In the process, it has sought to minimize class, race, and gender differences by creating a new estate - the consumer. Humanism, after all, has failed to generate much support for people to consider themselves as being "brothers" and "sisters" or "friends" or to be thought of as being "citizens." So, in this era, why not call the populace "consumers"? And we do.

Hence, it has become the simple, uncluttered operating principle of modern American capitalism that consumers should be constantly persuaded to want more and more in the "here and now." Life in the United States is increasingly based on the gospel of achieving material well-being in this world. American-style capitalism does not create a need for any rewards in the afterlife. No idea system should make promises it cannot fulfill. Therefore, having deprecated the need for religious faith, "the market" is now totally on its own to justify its existence for the first time since the consolidation of capitalism in the seventeenth and eighteenth centuries.

\section{The Challenges of Income Disparity}

As indicated, consumer capitalism derives its popular support from being able to satisfy the wants that it creates among the consumer population. From 1950 to 1978, virtually all strata of U.S. society shared in this quest. As shown in Figure 1, real family income for the bottom 20 percent of the population increased substan- 
Figure 1. Distribution of the Growth of U.S. Family Income by Quintile, 1950-1978

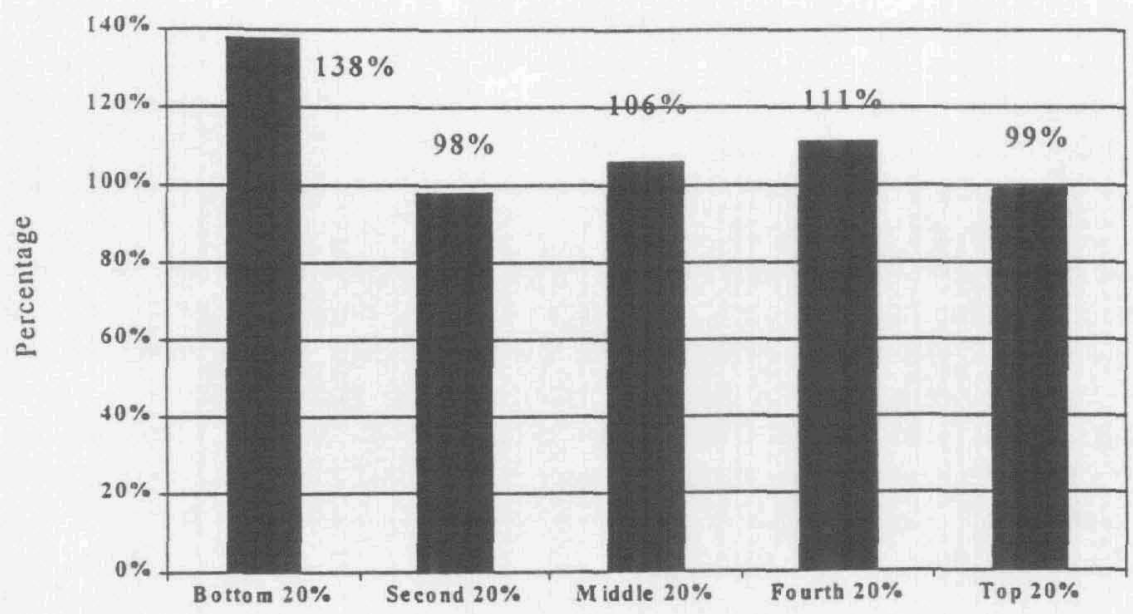

Family Income by Quintile

Source: U.S. Bureau of the Census [1996].

tially more than that for the top 20 percent (a 138 percent increase for the former versus a 99 percent increase for the latter). Starting in 1979, however, and continuing since, precisely the opposite has occurred see (Figure 2). The inflation-adjusted income of the top 20 percent of the population distribution grew by 26 percent while for the poorest it fell by 9 percent. Even more telling is the fact that in 1995, the richest 5 percent of U.S. families received 20 percent of the nation's total income while the bottom 40 percent received only 14.6 percent of the nation's total income [Reich 1997, E-14, E-15; Ryscavage 1995]. Moreover, since 1995, the poorest of the poor-those living at less than half the official poverty level-actually increased in number by one-half million families in 1996 [U.S. Bureau of the Census 1997, 1]. Thus, widening income disparity between the rich and the poor has become a distinguishing feature of the U.S. economy over the past two decades [U.S. Bureau of the Census 1996, 1]. Increasingly, significant segments of the population are lacking the income to convert their "wants" into consumer purchases. 
Figure 2. Distribution of the Growth of U.S. Family Income by Quintile, 1979-1995

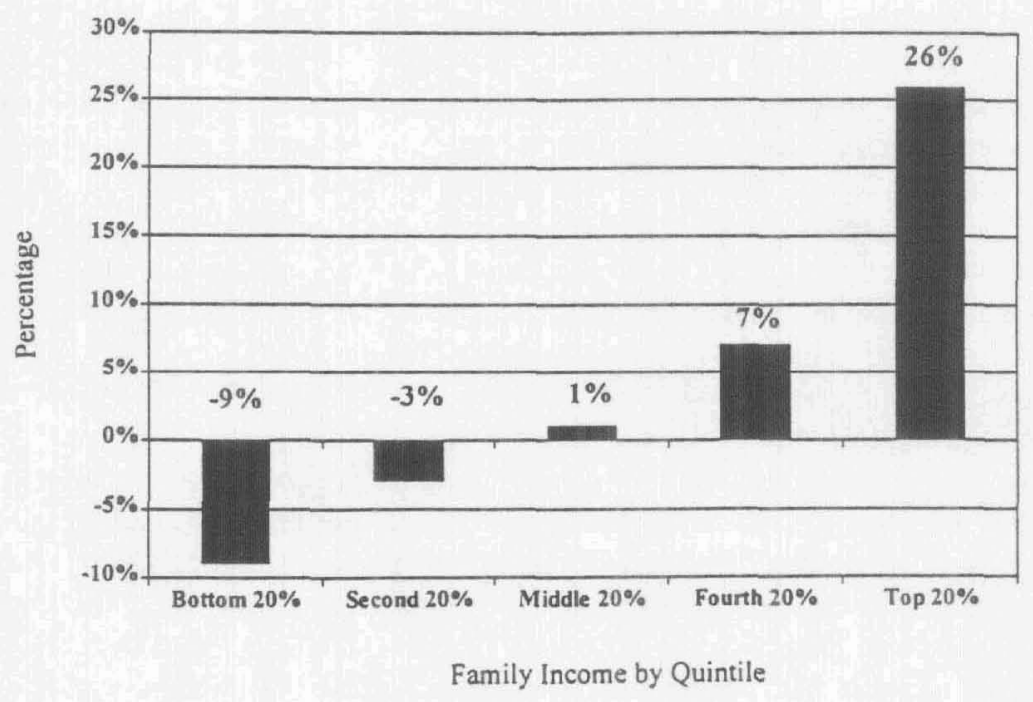

Source: U.S. Bureau of the Census [1996].

A similar polarization in wages has also occurred over this time span. Real wages for full-time weekly workers increased by about 11 percent since 1980 for the top 10 percent of the nation's wage earners; real wages declined by almost 10 percent over the same time interval for the lowest 10 percent of the distribution; and the median real wages for all workers fell by 3.6 percent over this time span [Reich 1997, E-14; see also Blau 1996]. Labor economist Richard Freeman has summarized this trend as follows: "Inequality has jumped to levels that raise doubts about the health of the U.S. economy and its ability to deliver to all the American dream of rising living standards" [Freeman 1997, 1]. 


\section{Capitalism and Income Distribution}

The issue of divergent income patterns in capitalist nations is, of course, not a new one. Indeed, the competitive principles inherent in capitalist economies mean, by virtual definition, that there will be "winners" and "losers." As Lester Thurow has written: "Capitalism has its virtues and vices. It is a wonderful machine for producing goods and services but . . . free markets also tend to produce levels of income inequality over the nation's history that are politically incompatible with democratic governments" [Thurow 1992, 17]. As a consequence, he notes that there is "the need for large social-welfare income transfer systems in every major industrial country" [Thurow 1992, 17]. In the case of the United States, income inequality has been a continual theme of social critics and social scientists [e.g., see George 1962; Riis 1957; Harrington 1962; Caudill 1963; Wilson 1987].

As noted earlier, from the end of World War II through the mid-1970s, there was a marked tendency in the United States toward income convergence. Beginning in the late-1970s and continuing ever since, the older pattern of income divergence has reemerged with a vengeance. In the private sector, the traditional pursuit of short-term profit maximization goals has been greatly amplified by a new array of business policies. Mega-mergers of enterprises have become commonplace; employment rolls of large corporations have been "downsized"; employee benefits have been slashed; the use of "contingent workers" has spread; and the practice of exorbitant salaries and stock bonuses for top corporate executives has become a standard compensation practice. Likewise, in the public sector over this period, an unprecedented array of public policies has been initiated to exacerbate the disparity trends. Not only have tax policies been introduced that disproportionately benefit the rich while redistributive social spending that benefits the less-fortunate has been curtailed, but mass immigration policies have been introduced that have swelled the ranks of the poorly educated and unskilled work force. Furthermore, a host of "free trade" policies (without any enforceable linkages to labor standards) has been implemented that benefit some while hurting others and that dampen efforts to maintain and to increase living standards for most American workers have been implemented with virtually no regard for the adjustment consequences felt by adversely affected individuals or by communities. And, of course, there has been a move to deregulate a host of industries in the transportation, financial, and telecommunication industries with little concern other than rhetoric for how consumers in general would be actually impacted.

As the 1990s come to an end, it is clear what the outcome of almost a quarter century of unbridled capitalism has produced. The rich have become richer, the poor poorer, and the middle class has been severely squeezed. As a consequence, the noted American historian Arthur Schlesinger, Jr. observed in 1997 that "even premier capitalists are appalled by what runaway capitalism has wrought" [Schlesinger 1997, 8]. 


\section{The Advent of Social Anarchy}

In its formative years three centuries ago, capitalism had the benefit of Christian religions in Europe to mitigate the suffering of the masses of workers and others who constituted the ranks of the "have nots, " as the twin forces of industrialization and market-oriented capitalism commenced their transformation of Western civilization. Those who were harshly treated, who lived lives in grinding poverty and squalor, and who failed to share in the emerging material wealth of their capitalist societies could at least be comforted by their faith. For Christianity proclaimed that it was they - the disenfranchised and economically disadvantaged-who would inherit the Kingdom of Heaven in the next world. Religion, in other words, served to preserve the social order during the tumultuous transition to the new world order of that era. In many ways, Christianity served as an unwitting "fifth factor of production." It not only supported the ethos of capitalism [Tawney 1947], it also provided much of the social glue needed to hold society together during this era of transformation.

But one of the startling accomplishments of American capitalism in the twentieth century has been that it has effectively replaced the teachings of Christianity with the teaching of the market place. It is life in the "here and now" where gratification is to be found. The values that are stressed, the symbols of success that are to be sought, and the lessons that are taught to the young are all those that serve the interest of "the market" in this world. In the process, however, the great painkiller of human suffering once offered by Christianity has been removed. The power of mitigation previously offered by religion has been reduced to zero in contemporary U.S. society.

The "market" is now entirely "on its own" with respect to its ability to preserve the social order for the first time in the history of capitalism. There is nothing else to hold society together. As a consequence, the tendency now is for economic controversies within U.S. society such as those associated with differential income patterns between racial, gender, and class groups to take on all of the trappings, all of the bigotry, all of the rhetoric, and all of the uncompromising ignorance of the religious wars of earlier centuries preceding the advent of capitalism.

The widening income disparity in the United States, with its parallel inducing of anxieties of unfulfilled consumer wants by a growing portion of the populace, does not mean that a revival of Marxism is in the offing. For revolutions of the downtrodden and the utopian promises of such social movements are pre-industrial concepts. The means of surveillance and the methods of suppression by the governments of industrialized states today are far too great to offer any prospect of success for such endeavors. Instead, when shoved to the wall, American capitalism will most likely yield to social anarchy -as it already seems to be doing-rather than to revolution. 
To the degree there is a way out of this seemingly inevitable dilemma, it must rest with a subordination of the short-term profit objectives of the business class to the long-term concerns for a stable and equitable society for the whole. This will require a redirection of societal resources toward greater investment in education, in the provision of universal healthcare, in environmental protection, in infrastructure investment, in providing affordable housing, in immigration reform, and in urban redevelopment. It will require a revival of interventionist government policies and the recognition of this imperative by those who seek leadership positions. Rather than surrender to the anarchy of the market, human intelligence should be used to buffer the hard edges of capitalism, to improve society, to enhance the quality of life, and to reduce human suffering.

\section{References}

Blau, Francine D., and Laurence M. Kahn. Wage Inequality. Washington, D.C:. American Enterprise Institute, 1996.

Caudill, Harry M. Night Comes to the Cumberlands. Boston: Little, Brown and Company, 1963.

Economic Report of the President: 1997. Washington, D.C.: U.S. Government Printing Office, 1997.

Freeman, Richard B. When Earnings Divide: Causes, Consequences, and Cures for the New Inequality in the U.S. Washington, D.C.: National Policy Association, 1997.

Galbraith, John K. The New Industrial State. Boston: Houghton Mifflin, 1967.

George, Henry. Progress and Poverty. New York: Robert Schalkenbach Foundation, 1962.

Harrington, Michael. The Other America. Baltimore: Penguin Books, 1962.

Reich, Robert B. "The Unfinished Agenda." Speech of the U.S. Secretary of Labor to the Council on Excellence in Government, Washington, D.C., January 9, 1997. Reprinted in the Daily Labor Report (January 10, 1997): E-13-E-17.

Riis, Jacob A. How the Other Half Lives. New York: Hill and Wang, 1957.

Ryscavage, Paul. "A Surge in Growing Income Inequality." Monthly Labor Review 118, no. 8 (August 1995): $51-61$.

Sagoff, Mark. "Do We Consume Too Much?" Atlantic Monthly 245, no. 6 (June 1997): 83-96.

Schlesinger, Arthur, Jr. "Has Democracy Failed?" Foreign Affairs 76, no. 5 (September-October 1997): $2-12$.

Soros, George. "The Capitalist Threat." Atlantic Monthly 245, no. 2 (February 1997): 45-57.

Tawney, R. H. Religion and the Rise of Capitalism. New York: Mentor Books, 1947.

Thurow, Lester. Head to Head: The Coming Economic Battle Among Japan, Europe, and America. New York: William Morrow and Company, Inc. 1992.

U.S. Bureau of Census. "A Brief Look at Postwar U.S. Income Inequality." P 60-101 (June 1996).

. "Income, Poverty Levels, and Health Insurance Reports." News Release, CB 97-162, September 29, 1997.

Wilson, William J. The Truty Disadvantaged: The Inner City, the Underclass, and Public Policy. Chicago: The University of Chicago Press, 1987. 